\title{
Karimunjawa Dan Sisa Benda Budaya Masyarakat Pulau-Pulau Di Perairan Utara Jawa
}

\section{Lucas Partanda Koestoro}

Keywords: north coast of java, small islands, cultural dispersal, artifact, history

\section{How to Cite:}

Koestoro, L. P. (1997). Karimunjawa Dan Sisa Benda Budaya Masyarakat PulauPulau Di Perairan Utara Jawa. Berkala Arkeologi, 17(2), 37-51. https://doi.org/10.30883/jba.v17i1.760

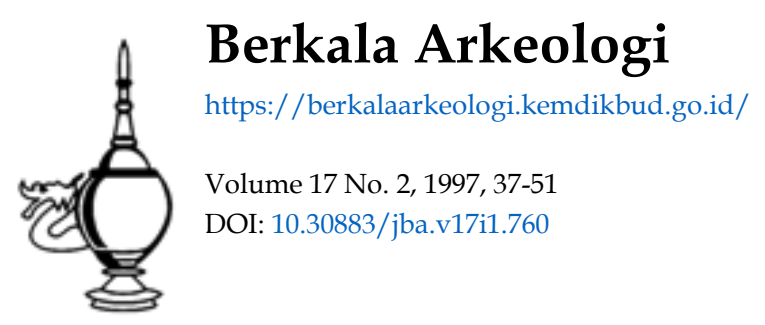

\section{c) (i) (2)}

This work is licensed under a Creative Commons Attribution-NonCommercial-ShareAlike $\underline{4.0 \text { International License. }}$ 


\title{
KARIMUNJAWA DAN SISA BENDA BUDAYA \\ MASYARAKAT PULAU-PULAU DI PERAIRAN UTARA JAWA
}

\author{
Lucas Partanda Koestoro \\ (Balai Arkeologi Yogyakarta)
}

\section{A. Pengantar}

Sebagian arkeolog dan sejarawan berkeinginan menyusun kembali cara dan bentuk okupasi pelayaran dan perdagangan nusantara masa lalu. Ini berkaitan dengan pembentukan gambaran tentang aktivitas manusia masa lalu, sehubungan dengan kondisi geografis dan sumberdaya lingkungan yang mempengaruhi bentuk kontak budaya yang berlangsung, adaptasi ekonomi dan religi, kekuatan teknologi, serta budaya masyarakat.

Untuk meraih itu, seyogyanya diawali dengan pembentukan ilustrasi yang menunjukkan peran kawasan-kawasan tertentu di nusantara dalam proses yang telah berlangsung. Pada kesempatan ini, yang akan diutarakan berkenaan dengan keberadaan Kepulauan Karimunjawa pada jalur pelayaran dan perdagangan dunia. Bersama dengan gugusan pulau/kepulauan lain yang seolah memagari perairan utara Jawa, dalam berbagai kesempatan dan kurun waktu, Karimunjawa ikut meramaikan lalu-lalang pelayaran dan perdagangan. Masyarakatnya mengalami sentuhan berbagai bentuk kekuatan, budaya dan lainnya, yang menambah perbendaharaan ragam kehidupan kawasan itu. Di balik itu, perannya sendiri ikut mewarnai sejarah nusantara. Adapun sisa benda budaya yang dikandungnya saat ini merupakan sarana pengenalan dinamika kehidupannya sejak dulu.

\section{B. Pendahuluan}

\section{B.1. Sekilas Kepulauan Karimunjawa}

Kepulauan Karimunjawa di wilayah Kecamatan Karimunjawa, Kabupaten Jepara, Jawa Tengah, menempati posisi astronomis antara: $5^{\circ} 48^{\prime}-5^{\circ} 59^{\prime} 9^{\prime \prime} \mathrm{LS}$ dan $110^{\circ}$ $9^{\prime} 26^{\prime \prime}-110^{\circ} 35^{\prime} 9^{\prime \prime}$ BT. Kepulauan ini terdiri atas 27 buah pulau dengan luas daratan sekitar 125 km2. Pulau yang banyak dihuni meliputi: Pulau Karimunjawa, Kemujan, Parang, Genteng, dan Pulau Nyamuk. Adapun pulau-pulau lain dimanfaatkan sebagai lahan pertanian (berkebun/berladang). Berdasarkan catatan tahun 1995, diketahui bahwa jumlah penduduknya 7510 orang yang sebagian besar (2193 orang) bermatapencaharian sebagai nelayan. Penduduk kepulauan ini menyebar tidak merata pada tiga wilayah desa. Adapun kebutuhan penduduk akan air bersih dipenuhi oleh mata air dan sumur di lingkungan pemukiman.

Di kepulauan yang berjarak antara 75 -- $100 \mathrm{~km}$ dari Pulau Jawa ini penduduknya didominasi tiga etnik, masing- masing Jawa, Madura dan Bugis. Dalam pergaulan sehari-hari digunakan bahasa Jawa yang bercampur logat Madura dan Bugis. 
Morfologi kepulauan itu meliputi: dataran rendah, perbukitan bergelombang, dan perbukitan. Wilayah dataran rendah berketinggian antara 0 -- 25 meter dpl, dan perbukitan bergelombang berketinggian sekitar 25 - 200 meter dpl. Gunung Walang di Pulau Kemujan adalah tonjolan topografi pada wilayah perbukitan bergelombang. Adapun wilayah perbukitan yang cukup luas dijumpai hanya di Pulau Karimunjawa. Gunung Bendera $(506 \mathrm{~m}$ ) adalah puncak tertinggi wilayah perbukitan yang berada di bagian tengah pulau tersebut.

Kepulauan ini tampak hijau karena tertutup hutan tropika, hutan sekunder, dan semak belukar. Jenis tanaman kerasnya antara lain: mahoni, jati, pinus, dewandaru, setigi, kalimasodo. dan bakau. Adapun hewan liamya meliputi: rusa, kera, biawak, penyu, dan ular.

Sisa benda budaya di Kepulauan Karimunjawa umumnya berada di sekitar pemukiman, dan sebagian besar daripadanya berupa kuburan yang kebanyakan dianggap sebagai tempat yang dikeramatkan sehingga sering diziarahi (pekaulan '). Sejak dahulu di wilayah ini telah terjalin kontak antara penduduk setempat dengan masyarakat lain. Interaksi yang berlangsung tidak sebatas dalam kaitannya dengan pelayaran dan perdagangan saja, melainkan ada pula yang ditimbulkan oleh terjadinya perbenturan politik dan kekuasaan, sebagaimana diutarakan dalam beberapa sumber. Sumber Cina misalnya, menyebutkan bahwa pada tahun 1293 utusan Khubilai Khan, yakni Shihpi dan Kan Shing, selepasnya dari Pulau Belitung bertolak ke Jawa. Di Karimunjawa mereka sandar, menunggu kesempatan untuk memasuki Tuban sebelum memudiki Sungai Kali Mas lewat Sedayu (Groeneveldt, 1960).

\section{B.2. Penelitian di Perairan Utara Jawa}

Penelitian eksploratif yang dilakukan Balai Arkeologi Yogyakarta pada tahun 1986 merupakan awal pengenalan potensi sumberdaya arkeologi pulau-pulau di perairan utara Jawa Tengah dan Jawa Timur (Koestoro \& Abbas,1986; Koestoro \&

\footnotetext{
1 Tempat orang mengikrarkan kaul. Kata kaul bermakna janji seseorang secara sadar dan rela untuk berbuat sesuatu - yang secara umum tidak dituntut darinya - yang lebih berkenan kepada Allah daripada sebaliknya. Ini dilakukan dengan cara mempersembahkan: diri, perbuatan, atau barang dalam pengabdian kepada Allah.
}

Namun sebagaimana yang kerap dijumpai di berbagai tempat lain yang dikeramatkan. kebanyakan kaul itu lebih dikaitkan dengan permohonan-permohonan perorangan. Kemudian, apabila dalam kehidupan yang dijalaninya dirasakan bahwa permohonan itu terkabul. barulah kaul dilaksanakan. Adapun kenduri * upacara makan bersama yang bersifat religius - adalah salah satu bentuk bovar koul (kaulan, bahasa Jawa) yang kerap dilakukan di sebuah pekaulan, termasuk juga di Kepulauan Karimunjawa. 
Abbas, 1997). Hasil yang diperoleh dari Pulau Bawean - terletak di antara Kepulauan Karimunjawa dan Kepulauan Masalembu - mengindikasikan keberadaan sisa benda budaya masa lalu yang menarik untuk diteliti. Selain stupika yang memperlihatkan sentuhan budaya berlatar Budha, ditemukan pula sisa benda budaya Islam dan jejak bangsa Eropa. Posisinya yang strategis, seolah menjembatani Jawa dan Kalimantan. memunculkan corak tertentu pada tinggalan budayanya.

Aktivitas arkeologis tahun 1986 itu dilanjutkan pada tahun 1995 di Kepulauan Karimunjawa (Jawa Tengah), tahun 1996 di Kepulauan Sapudi-Raas (Jawa Timur). dan tahun 1997 di Kepulauan Kangean (Jawa Timur). Sebelumnya, perhatian para ahli terhadap gugusan kepulauan di perairan utara Jawa lebih berkaitan dengan aspek historis dan etnografis. Tersebut di sini, antara lain, C Lekkerkerker (1935) yang membicarakan ikhwal masyarakat Kepulauan Sapudi dan Bawean dari masa ke masa; David E Sopher (1977) berkenaan dengan sea nomads di Kepulauan Kangean; atau Sulaiman $(1981 / 1982,1983 / 1984)$ tentang gerabah dan kerapan sapi di Madura.

Sampai tahun 1995, sumberdaya arkeologi Kepulauan Karimunjawa dapat dikatakan tidak dikenal karena belum ada penelitian tentangnya. Sekilas mengenai sejarah perekonomiannya, dan itupun berkenaan dengan kondisi Karimunjawa awal abad 19. pernah disampaikan oleh GL Gonggrijp (1915).

\section{Sisa Benda Budaya}

Sisa benda budaya yang dapat di kemukakan adalah yang terdapat di dua desa dari tiga desa yang ada di wilayah Kecamatan Karimunjawa. Masing-masing Desa Karimunjawa (di Pulau Karimunjawa dan Pulau Genteng) dan Desa Kemujan (di Pulau Kemujan). Sebagian besar obyek yang dapat dikenali itu berada tidak terlalu jauh dari garis pantai. Beberapa keterbatasan menyebabkan belum dipenuhinya catatan tentang potensi yang (mungkin) terdapat di wilayah Desa Parang di Pulau Parang dan Pulau Nyamuk.

\section{C.1. Desa Karimunjawa \\ C.1.1. Pulau Karimunjawa}

Sisa benda budaya di pulau ini berupa peninggalan kepurbakalaan: Ujung Benteng. Balai Kecamatan, Makam Cina, Makam Eropa, Makam Danyangjoyo, Makam Sunan Nyamplung, dan Makam Sayyid Kambang/Kemloko.

\section{C.1.1.1. Ujung Benteng dan Balai Kecamatan}

Berada di ujung baratdaya Pulau Karimunjawa, lokasi ini menyimpan sisa sebuah pusat kekuasaan, simbolis dan fisis. Obyeknya berupa bangunan karya arsitektur bergaya kolonial (dengan detil berlanggam Eropa di beberapa bagiannya) yang sekarang digunakan sebagai Balai Kecamatan/Pesanggerahan, dan lapangan terbuka yang dahulu dikatakan sebagai bagian dari sebuah benteng. 
Kawasan ini merupakan jantung pemerintahan kepulauan tersebut, yang ditandai oleh Kantor Kecamatan. Koramil, Polsek. dan kantor Desa Karimunjawa. Selain itu adalah juga kantor Dinas Perikanan, pelabuhan dan kantor Administrator Pelabuhan. serta Stasiun Bumi Kecil (PT Telkom).

\section{C.1.1.2. Makam Cina dan Makam Eropa}

Pada tegalan di Dusun Karimunjawa dijumpai sisa beberapa kuburan Cina. Masyarakat tidak mengenal lagi tokoh-tokoh yang dimakamkan di sana. Pada pemukiman di dekatnya. dijumpai dua buah bongpai. ${ }^{2}$ Masing-masing terbuat dari batuan granit, bentuknya persegi empat, dan berisi tulisan yang menggunakan aksara Cina. ${ }^{3}$

Bongpai pertama, yang terdapat di pekarangan rumah Sdr. Suyitno di Dusun Karimunjawa, ternyata diperuntukkan bagi seorang wanita dari keluarga/marga (she) Wang, isteri seorang laki-laki bermarga Liem. Wanita tersebut dilahirkan di Sakhmen (di wilayah Provinsi Fukien, Cina Selatan), yang meninggal pada tahun ke 17 dari masa bertahtanya raja Kwang Chw/Kwang Shui. Raja dari dinasti Ching (Akhir) ini penguasa Cina tahun $1875-1908$.

Bongpai lain juga di lingkungan Dusun Karimunjawa, adalah milik seorang laki-laki yang bernama A-ching (nama she -nya tidak diketahui karena tulisannya tidak terbaca lagi). Diperkirakan bahwa bongpai ini juga berasal dari periode yang sama dengan bongpai pertama (akhir abad XIX).

Sekitar 250 meter di sebelah timur kuburan Cina, dijumpai dua makam Eropa. Masing-masing berbentuk empat persegi panjang dengan bahan karang, berlepa. Kubur yang satu berukuran lebih kecil daripada kubur lainnya. Informasi setempat menyebutkan bahwa itu adalah makam keluarga pejabat Belanda yang meninggal pada awal abad XX.

\section{C.1.1.3. Makam Danyangioyo}

Di Dusun Kapuran, di sebelah timurlaut makam Cina, pada lahan cadangan desa terdapat sebuah cungkub yang menaungi makam Danyangjoyo. Tokoh ini adalah

2 Bangpai adalah kata yang lazim didengar dan digunakan di Indonesia bagi penyebutan nisan makam-makam orang Cina yang di dalamnya berisi pertulisan singkat (epitataph).

3 Pembacaan atas foto bongpai bertulisan itu dilakukan oleh Sdr. Tan Swee Ban dari Vihara Budha Prabha/Kelenteng Hok- ling di Gondomanan. Yogyakarta.

Penulisan bahasa Cina menggunakan sistem karakter (huruf), bukan sistem abjad. Jadi berbeda dengan abjad, setiap karakter merupakan suatu simbol yang mewakili suku kata (silabel) atau satu kata penuh. 
cikal-bakal (orang yang hahud alus) Karimuniawa Versi selempat menyebuthan bahwa Danyangjoyo tiba lebih dahulu di Karimunjawa daripada Sunan Nıamplung.

\section{C.1.1.4. Makam Sunan Nyamplung}

Kompleks makam di wilayah Dusun Nyamplungan ini berada di pesisir barat pada ketinggian sekitar $140 \mathrm{~m}$ dpl. Tokoh utama yang dimakamkan di sana adalah Mbah Amir Khasan atau Sunan Nyamplung yang dipercaya sebagai putera Sunan Muria. Versi lain menvebutkan bahwa Sunan N̦amplung adalah putera Sunan Kudus. Kedatangannya ke Karimunjawa berkenaan dengan misi keagamaan. yakni penyebarluasan agama Islam.

Di sana terdapat pula sisa mustaka/kemuncak terakota berbentuk nanas. Sumber lokal menyatakan bahwa benda yang biasa digunakan sebagai puncak bangunan masjid itu kiriman Sunan Muria setelah mengetahui bahwa Sunan Nyamplung menyelenggarakan sebuah pesantren.

Selain itu. sebagaimana yang dikenal masyarakat. di dekat lokasi makam terdapat sisa tunggul pohon dewandaru - tongkat Sunan Nyamplung yang berubah menjadi pohon - yang dikatakan sebagai cikal-bakal pohon-pohon dewandaru di Kepulauan Karimunjawa. Kekeramatan dan keampuhan pohon atau bagian pohon dewandaru dari Karimunjawa. sebagaimana yang dipercaya banyak orang, sebetulnya berkenaan dengan pohon yang sekarang hanya tersisa tunggulnya saja.

4 Sunan Muria - dikenal pula dengan nama Sunan Muriapada - adalah sebutan bagi Raden Prawoto yang mensosialisasikan agama Islam melalui pendekatannya ke kalangan pedagang. nelayan. dan pelaut. Dianggap juga sebagai pencipta gending sinom dan kinanti. beliau tetap mempertahankan gamelan sebagai satu-satunya kesenian Jawa yang sangat digemari rakyat dan menggunakannya sebagai sarana memasukkan rasa Islam kepada rakyat sehingga dengan tidak terasa mereka dibawanya kepada mengingat Tuhan (Aboebakar,1955). Sebagian orang juga percaya bahwa Sunan Muria - atau Raden Umar Said - adalah putera Sunan Kalijaga yang kawin dengan adik Sunan Ngudung (kakak Sunan Kudus) dan berputera Pangeran Santri yang belakangan disebut Sunan Kadilangu.

5 Sunan Kudus. nama bagi Djafar Shadiq. adalah penyiar Islam di pesisir utara Jawa Tengah. Konon adalah pencipta gending maskumambang dan mijil. selain pujangga yang banyak mengarang dongeng-dongeng agama (Aboebakar.1955). Disebut sebagai wallinyul ilm karena pengenalannya yang mendalam mengenai tauhid. usuluddin. hadits. mantiq dan fiqih.

Dalam sejarah Jawa Tengah. pada pertengahan pertama abad ke- 16 Sunan Kudus telah memainkan peran yang cukup penting. Termasuk sebagai salah satu dari wali somgu. dalam cerita tutur Jawa tampil sebagai penyebar agama yang ulung. ia tidah segan-segan menggunakan kekerasan sebagaimana yang tampak misalnya pada tindakan penghukuman terhadap Syekh Lemah Abang (Graaf \& Pigeaud.1985). 


\section{C.1.1.5. Makam Sayyid Kambang/Kemloko}

Pada kaki bukit yang memagari Teluk Kemloko di pantai timur Pulau Karimunjawa. sekitar 150 meter dari garis pantai, terdapat sebuah makam berpagar tembok rendah. Tokoh yang dimakamkan pada areal yang dipenuhi tumbuhan jambu mete itu adalah Sayyid Kambang. yang dipercaya sebagai anak angkat Sunan Muria.

\section{C.1.2. Pulau Genteng}

Sisa benda budayanya berupa: Makam Mbah Endang Setiawati. Makam Gadung Wulung/Klenting Wesi, dan Wreck-site' Gunung Lor.

\section{C.1.2.1. Makam Mbah Endang Setiawati}

"Punden" ini berada pada sebuah gumuk yang berketinggian sekitar 10 meter dpl. Jaraknya hanya 150 meter dari garis pantai barat Pulau Genteng. "Punden" Mbah Endang Setiawati merupakan tumpukan/gundukan kecil batuan laterit kecoklatan yang masing-masing telah mengalami pengerjaan (sebagaimana dapat diketahui dari takuk-takuk di bagian tepi batuan). Pekaulan itu menempati sebagian lahan milik H Nafsiah.

\section{C.1.2.2. Makam Gadung Wulung/Klenting Wesi}

"Punden" yang dibentuk dari batuan alam ini berada di puncak Bukit Genteng. bagian tertinggi dari Pulau Genteng. Pada saat-saat tertentu orang berdatangan untuk menziarahinya.

\section{C.1.2.3. Wreck-site Gunung Lor}

Sekitar 150 meter dari tepi pantai timur Pulau Genteng. terdapat banyak pecahan keramik yang menghampar pada areal seluas tidak kurang dari 600 meter persegi (30 $\mathrm{m} \times 20 \mathrm{~m}$ ). Fragmen mangkuk. piring, vas. cepuk dan guci di kedalaman 1 -- 1.5 meter itu diperkirakan merupakan produk kiln Cina awal abad ke-18 (masa awal dinasti Ching). Dapat disebutkan bahwa keberadaan pecahan keramik di sana tentu berkaitan dengan peristiwa karamnya perahu yang menjadi sarana pengangkutannya.

\section{C.2. Desa Kemujan}

C.2.1. Pulau Kemujan

Makam Sayyid Abdullah Legon Kluwak adalah satu-satunya monumen sisa benda budaya masyarakatnya dahulu yang dijumpai di pulau tersebut.

\section{Makam Sayyid Abdullah Legon Kluwak}

Berbeda dengan makam Sayyid Abdullah (Wan Dullah) di lingkungan kompleks makam Sunan Nyamplung. makam tokoh Sayyid Abdullah (Legon Kluwak) ini 
ditempatkan dalam sebuah cungkub. Masyarakat sekitar percaya bahwa Sayyid Abdullah adalah keturunan Hasan-Husen (cucu Nabi Muhammad).

Cungkub di kompleks tersebut berukuran $5 \mathrm{~m} \times 4.5 \mathrm{~m}$. dan makam Sayyid Abdullah sendiri berukuran $390 \mathrm{~cm} \times 80 \mathrm{~cm}$.

\section{Migrasi Dan Dinamika Budaya Karimunjawa}

Perjalanan sejarah Karimunjawa diwamai oleh migrasi. sehingga tidak mengherankan bila pada saat ini populasi penduduknya didominasi tiga etnik. masing-masing Jawa, Madura dan Bugis. Bahasa yang digunakan sehari-hari adalah bahasa Jawa yang bercampur logat Madura dan Bugis.

Apabila kita membandingkan keadaan itu dengan Pulau Bawean misalnya, akan tampak bagaimana sebuah pulau/kepulauan menerima banyak pengaruh budaya dari etnik yang mendiami "pulau induk" -nya. Bila di Pulau Bawean, "warna dan kesan" Madura yang terasa kental dalam kehidupan keseharian masyarakatnya dikarenakan letaknya yang berdekatan dengan Pulau Madura, maka Kepulauan Karimunjawa menyerap banyak "masukan" dari Pulau Jawa.

Erat berhubungan dengan itu, perolehan data juga menumbuhkan impressi yang kuat bahwa kelompok etnis Jawa adalah yang pertama kali datang ke kawasan tersebut. Tampaknya. yang menjadi push factors migrasi tersebut, selain karena letak yang berdekatan adalah: a. menghindari kekacauan akibat konflik politik di Jawa: b.

6 Hasan bin Ali (625 - 672) adalah imam kedua penganut Islam Syiah. dan Husen bin Ali (626 - 680), adiknya, adalah imam ketiga yang gugur sebagai sahid di Karbala pada tanggal 10 Muharram 680 oleh serangan serdadu Yazid. Penokohan keduanya berkenaan dengan kondisi Syiah (aliran dalam Islam) yang setelah wafatnya Nabi Muhammad mempercayai kepemimpinan Ali bin Abu Thalib dan keturunannya. Dalam Syiah kepemimpinan umat Islam sepeninggal Nabi Muhammad tidak diserahkan kepada pilihan umat tetapi sudah ditentukan oleh Nabi, yakni Ali dan keturunannya.

Berkaitan dengan keberadaan makam tokoh yang dikatakan sebagai keturunan Hasan-Husen di Legon Kluwak. Desa Kemujan itu, dapat disebutkan bahwa di sekitamya tidak dijumpai tanda - berupa sisa benda budaya dan upacara - yang mengacu pada keberadaan aliran Syiah.

7 Migrasi dalam arti luas dapat didefinisikan sebagai perubahan tempat tinggal secara permanen atau semi permanen. Di dalamnya tidak ada pembatasan yang menyangkut jarak perpindahan maupun sifat yang mendasarinya (terpaksa atau sukarela). Setiap migrasi tentu memiliki tempat asal. daerah tujuan, serta bermacam-macam rintangan yang menghambat. Adapun faktor jarak perpindahan - satu dari beberapa penghalang antara - merupakan faktor yang mesti hadir (Lee.1995). 
memperbaiki kehidupan perekonomian; atau c. khusus datang ke Kepulauan Karimunjawa menjalankan misi agama.

Dalam perkembangannya, dari waktu ke waktu migrasi tersebut semakin meningkat. Secara umum, peningkatan migrasi disebabkan oleh berkembangnya sarana perhubungan. industri kerajinan. dan perdagangan (Lee.1995). Sebagian - atau mungkin pula seluruh - faktor itu pasti berlaku pula dalam kasus peningkatan migrasi di Kepulauan Karimunjawa.

Berbicara tentang keberadaan etnik lain di kepulauan tersebut, unsur yang "mengundang" kedatangannya (pull factors) juga berhubungan dengan peran Jepara sebagai bandar yang ramai sejak dahulu. Lokasi Karimunjawa yang mengantarai Jawa dan pulau-pulau lain di nusantara. juga menupakan alasan untuk menjadikannya sebagai tempat persinggahan. Bila awalnya hanya untuk sementara waktu, dan hal ini dapat diakibatkan oleh karakter angin di perairan tersebut yang pada masanya berpengaruh besar terhadap kondisi teknologi pelayaran, belakangan lokasi itu digunakan untuk menetap. Contohnya, sebagaimana tertera dalam sumber Cina, adalah pemanfaatan kepulauan tersebut sebagai titik persinggahan armada Khubilai Khan di akhir abad XIII sebelum memasuki daerah tujuannya di daratan Jawa. Berbagai alasan dapat dikenakan atas kesinggahan mereka. Menunggu ombak reda dan angin yang mampu membawanya ke Pulau Jawa, mengisi perbekalan, atau hanya menanti "hari baik" untuk melakukan "penghukuman" atas Krtanagara.

Sumber Cina lain dari abad XV, dikenal dengan nama Shun Feng Hsiang Sung. merupakan nautical compendium yang memuat route pelayaran antara Cina Nusantara. Chi-li-wen atau Kepulauan Karimunjawa digambarkan sebagai tempat yang cukup penting bagi pelayaran antara Wu-yu di dekat Amoy (Cina), dengan Tuban dan Jaratan dekat Gresik (Mills, 1979).

Seiring dengan gaya hidup masyarakat kolonial yang pada masanya hidup berkecukupan, masyarakat Batavia memanfaatkan pula potensi sumberdaya alam Kepulauan Karimunjawa. Selain menggunakan kayu eben dari Mauritius dan India. pengrajin mebel Belanda di Batavia sampai akhir abad ke-18/awal abad ke-19 juga menggunakan kayu Jawa Karimun dalam pembuatan mebel-mebel indah untuk memenuhi kebutuhan sekelompok anggota masyarakat yang merasa harus menyelaraskan kemewahan itu dengan status sosial yang disandang dan dibanggakannya.

Diduga bahwa yang disebut sebagai kayu Jawa Karimun oleh sumber Belanda itu adalah kayu sonokeling (Dalbergia latifolia) dari Karimunjawa. Kebutuhan yang cukup tinggi akan jenis kayu tersebut tentu berpengaruh besar atas jumlah pendatang ke Kepulauan Karimunjawa, yang pada awalnya bekerja pada sektor perkayuan. 
Dikaitkan dengan sumber Belanda pada masa berikutnya, penguasaan lokasi itu oleh Belanda berkenaan dengan penjagaan jalur pelayaran di sana sekaligus pengamanan bandar Jepara yang begitu ramai. Laut Jawa adalah tempat lalu- lalangnya perahu layar berisi komoditi dagang yang berharga. Kepulauan Karimunjawa merupakan bagian tengah jalur barat- timur nusantara. Pentingnya tempat itu antara lain ditandai dengan penugasan seorang assistent resident Belanda di sana. Penempatannya disertai pasukan yang cukup besar jumlahnya pada abad XIX (Gonggrijp, 1915). Pembangunan benteng, yang sisanya hanya berupa cerita serta "penggalan" konstruksi bata yang tertanam pada areal yang disebut Ujung Benteng, merupakan bagian dari upaya pengamanan kawasan tersebut.

Keamanan juga hal yang patut dikemukakan sebagai unsur "pengundang" kedatangan sekelompok orang ke sebuah kawasan. Ditempatkannya sebuah kekuatan militer di sana tampaknya ikut memuluskan aktivitas perekonomian. Hal ini "terbaca" oleh perantau Cina yang kemudian bermukim dan berniaga di Karimunjawa. Peninggalan berupa makam Cina dan bongpai bertulisan Cina, merupakan bukti keberadaan etnis tersebut pada akhir abad XLX. Sumber lain menyebutkan bahwa "pesinggahpesinggah" berperahu betah hidup di sana karena lingkungan alamnya membantu pemenuhan kebutuhan hidup sehari-hari. Tersedianya air tawar serta lahan yang dapat diolah; hutan yang kayu- kayunya memungkinkan dijadikan ramuan tempat tinggal dan perahu; hasil laut bernilai ekonomi tinggi; maupun frekuensi kedatangan

8 Di Indonesia dikenal empat bahasa Cina, yakni bahasa- bahasa Hokkien, Toa-Chiu, Hakka, dan Kanton. Ini disebabkan karena orang Cina di Indonesia bukan merupakan satu kelompok yang berasal dari satu daerah di Cina. Mereka terdiri atas beberapa sukubangsa yang berasal dari dua wilayah provinsi, yalni Fukien dan Kwangtung.

Sukubangsa Hokkien, salah satu dari sukubengsa itu, merupakan migran Cina terbesar ke Indonesia sejak abad ke-16 sampai kira-kira pertengahan abad ke-19. Mereka berasal dari provinsi Fukien bagian selatan, daerah yang sejak dulu berperan penting dalam pertumbuhan perdagangan Cina ke seberang lautan. Kepandaian berdagang yang ada dalam kebudayaan mereka masih tampak pada orang Cina di Indonesia. Orang Hokkien dan keturunannya banyak terdapat di Indonesia Timur, Jawa Timur, Jawa Tengah, dan pantai barat Sumatera. Adapun daerah di Indonesia yang pertama - dan paling tams - didatangi perantau Hokkien, sejak abad ke-16, adalah Jawa Timur dan Jawa Tengah. Kedatangannya tidak dalam gelombang- gelombang besar melainkan dalam kelompok-kelompok kecil yang didominasi laki-laki (Vasanty,1976).

Berbicara tentang etnik Cina di Karimunjawa, berbeda dengan keadaan beberapa tahun berselang. saat ini hanya dijumpai satu keluarga keturunan Cina yang berdiam di sana. Keterangan yang diperoleh menyebutkan bahwa hal itu terjadi lebih karena faktor ekonomi. Kepindahan mereka ke Jawa/Jepara berkenaan dengan suramnya sektor perniagaan yang selama ini ditekuni. 
perahu yang cukup tinggi. adalah alasan yang utama. Begitupun dengan kondisi pantai yang cukup landai. semua inenjadikannya surga sebuah "pendaratan".

Hingga akhir tahun 1960-an. banyak pendatang dari Sulawesi yang sejak awal telah menetapkan Kepulauan Karimunjawa sebagai tempat tujuan. Alasan utamanya karena produk ikan yang sangat baik. Berperahu dalam rombongan keluarga yang tidak terlalu besar, mereka pergi meninggalkan daerah asal, mendarat, dan hingga kini menetap di Karimunjawa.

Pada kasus kependudukan Kepulauan Karimunjawa. secara umum tentu dapat disepakati bahwa besaran arus migrasi yang didorong oleh keinginan untuk memperbaiki kehidupan perekonomiannya tidak dapat dibandingkan dengan arusarus migrasi yang ditimbulkan oleh sebab lain (Lee.1995). Aspek ekonomi yang lebih menguntungkan dibandingkan dengan daerah asalnya. dapat diduga sebagai faktor yang memotivasi kedatangan etnis lain ke Kepulauan Karimunjawa.

Selain aspek lingkungan dan sumberdaya alamnya, kesamaan motivasi dan latar budaya marginal pendatang-pendatang itu merupakan modal untuk hidup bersama. Konflik jarang sekali terjadi, sebaliknya justru timbul penyesuaian diri dengan gaya hidup dan budaya masyarakat pendahulunya. Keterangan tokoh masyarakat telah membuktikannya.

Dalam beberapa hal, pendatang itu tetap mempertahankan adat kebiasaannya. Contohnya terlihat pada bentuk rumah tinggal, perahu dan peralatan menangkap ikan, maupun upacara-upacara yang diselenggarakan dalam kaitannya dengan life cycle. Berkenaan dengan ini pula. menarik untuk diamati adalah cara mereka menyikapi lingkungan alamnya. Di Batu Lawang. sebuah kampung di Desa Kemujan. dijumpai makam yang menggunakan bunga karang sebagai jiratnya.

9 Seorang penduduk Dusun Kapuran, Desa Karimunjawa yang bemama La Talanda ( 50 tahun) menceritakan bahwa pada tahun 1962 ia dengan enam orang teman sekampung menangkap ikan hingga ke Kepulauan Karimunjawa yang ketika itu dikenal amat kaya dengan berbagai jenis ikan. Setelah menyaksikan sendiri hasil tangkapan yang begitu baik. maka ketika perahu dan teman-temannya kembali ke tempat asalnya di Pulau Buton (Sulawesi Tenggara), ia memutuskan untuk tinggal di Karimunjawa sebagaimana yang telah direncanakan. Belakangan ia kawin dengan orang Jawa yang berasal dari Jepara. Hingga saat ini beliau tetap menjalani kehidupan sebagai nelayan.

Narasumber lain menceritakan bahwa beberapa pendatang Sulawesi di Karimunjawa semula adalah awak perahu layar yang beberapa puluh tahun berselang masih banyak mengarungi Laut Jawa membawa komoditi antar pulau. Secara tradisional. disebutkan bahwa Kepulauan Karimunjawa - bersama-sama Pulau Bawean dan Kepulauan Masalembo di sebelah timumya - adalah titik persinggahan perahu-perahu yang melayari route Jakarta -- Sulawesi (Selatan). 
Dapat disimpulkan bahwa di luar alasan yang berkenaan dengan kepentingan sosialpolitis, kondisi lingkungan alam adalah hal yang perlu dikenali sebagai alasan tumbuhkembangnya masyarakat di sana. Selanjutnya. tummbuhkembangnya kebudayaan menyusul seiring dengan aktivitas perekonomian. Keseluruhannya membentuk kelaziman bahwa pemukim pantai adalah masyarakat yang terbuka. Berbeda akan pengenalan kita pada dunia agraris yang terlalu terikat secara statis kepada tanah. sawah. ladang, dan hutannya, dunia pelayaran dan perdagangan memerlukan dinamika dan aktivitas yang luar biasa. Bila dunia pelayaran dan perdagangan memerlukan kemerdekaan, persamaan kedudukan sosial. dan hak politik. maka dunia agraris yang feodal cenderung ingin mempertahankan statisnya sistem kasta. dengan perbedaan kedudukan sosial, dan diskriminasinya dalam hakhak politik.

\section{E. Penutup}

Benda bersejarah dan purbakala yang tersisa di Kepulauan Karimunjawa merupakan akibat dari perjalanan panjang kawasan ini dalam sejarah kebudayaan Nusantara. Sebagai bukti otentik yang menghubungkan zaman modern dengan masa lalunya. tentu diperlukan pengelolaan yang seksama agar dapat dimanfaatkan secara optimal dan bijaksana.

Di samping itu, nilai penting yang terkandung pada sisa benda budaya sebagai benda bersejarah dan purbakala di kawasan ini, merupakan sesuatu yang patut dibanggakan oleh masyarakatnya. Seyogyanya ini dapat dijadikan sebagai bagian "muatan lokal" dari paket pendidikan yang ada. Diberlakukan sebagai bahan kajian dalam pernahaman sejarah lokal sehubungan dengan proses pembentukan jati diri daerah.

Hal lain yang dapat disampaikan berkenaan dengan sosialisasi Islam. yang melalui sisa benda budaya di Kepulauan Karimunjawa berupa makam Sunan Nyamplung beserta cerita tutur yang menyertainya, membawa kita untuk menyelami peran Wali Songo. Secara khusus pada peran Sunan Muria yang berdasarkan historiografi Jawa merupakan tokoh sejarah pada masanya. cerita tentang kedekatannya dengan masyarakat kalangan pedagang, pelaut, dan nelayan (dalam konteks penyampaian syiar Islam), menjadi semakin nyata.

Dalam era pembangunan kini, proses pembangunan wilayah berkaitan dengan kegiatan pengelolaan sumberdaya, yang meliputi tidak saja sumberdaya manusia. sumberdaya alam, maupun sumberdaya buatan, melainkan pula sumberdaya budaya. Keseluruhannya harus dikelola dengan serasi. seimbang, dan selaras bagi kemanfaatan masyarakat dalam arti yang luas. Penanganan secara koordinatif atas benda-benda cagar budaya yang terdapat di sana adalah bagian dari pengelolaan itu. Terlebih bila diingat bahwa pembangunan, yang cenderung berkonotasi pengubahan 
muka lahan. bergerak begitu cepat. Tidak saja yang dilaksanakan oleh pihak pemerintah. melainkan pula yang menyertakan partisipasi pihak swasta

Mengakhiri tulisan ini. dengan mengingat hal-hal tersebut di atas. dapat dikatakan bahwa pengungkapan sumberdaya arkeologi kawasan ini belum sepenuhnya dilakukan, sehingga dirasa perlu untuk menyelenggarakan penelitian lanjutan dengan memanfaatkan pula studi etnoarkeologi.

10 Potensi pariwisata Kepulauan Karimunjawa cukup besar sehingga layak dikembangkan menjadi daerah tujuan wisata. Untuk lebih mengoptimalkan potensi itu, termasuk di dalamnya Taman Laut Nasional Karimunjawa (yang penetapannya berlangsung belum lama ini) serta sisa benda budaya setempat. jelas diperiukan pengelolaan yang harus ditangani secara khusus. Bagaimanapun. upaya pengembangan kepariwisataan di sana memerlukan penyempurnaan infrastruktur maupun pengembangan rencana induk kawasan yang meliputi faktor-faktor sosial. budaya, ekonomi. dan lingkungan. 


\section{KEPUSTAKAAN}

Aboebakar, H. 1955. Sedjarah Mesdiid Dan Amal Ibadah Dalamnia. DjakartaBandjarmasin: Adil \& Co.

Gonggrijp, GL. 1915: De Karimoen Djowa-eilanden, dalam KT 3, hal. 313--341

Graaf, HJ de. 1985. Awal Kebangkitan Mataram. Masa Pemerintahan Senapati. Jakarta: Grafiti Pers

1986. Puncak Kekuasaan Mataram. Jakarta: Pustaka Grafitipers

Graaf, HJ de \& Th. G. Th. Pigeaud. 1985. Kerajaan-Keraiaan Islam Pertama Di Jawa. Jakarta: Grafiti Pers

Groeneveldt, WP. 1960. Historical Notes On Indonesia and Malaya. Compiled From Chinese Sources. Jakarta: Bhratara

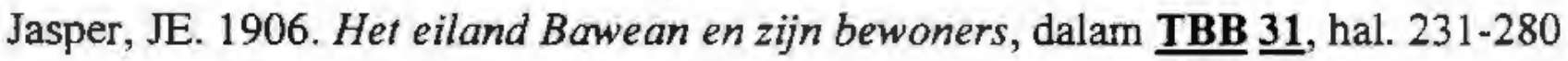

Koestoro, Lucas Partanda. 1993. Kemungkinan Pengembangan Arkeologi Maritim Dalam PJPT ㅍ. Makalah dalam EHPA 1993 di Yogyakarta

1995/1996. Penelitian Pasang Surut Budava Masyarakat Pulau Di Perairan Utara Jawa Tahap I Di Kepulauan Karimunjawa. Yogyakarta: Balai Arkeologi Yogyakarta (tidak diterbitkan)

1996/1997. Hasil Budaya Maritim Masyarakat Pulau Di Perairan Utara Jawa Tahap II Di Kepulauan Sapudi-Raas. Yogyakarta: Balai Arkeologi Yogyakarta (tidak diterbitkan)

1997/1998. Hasil Budaya Maritim Masyarakat Pulau Di Perairan Utara Jawa Tahap III Di Kepulauan Kangean. Yogyakarta: Balai Arkeologi Yogyakarta (tidak diterbitkan)

Koestoro, Lucas Partanda \& Novida Abbas. 1986. Survei Arkeologi Islam Di Pulau Bawean, Jawa Timur. Yogyakarta: Balai Arkeologi Yogyakarta (belum diterbitkan) 
Koestoro. Lucas Partanda \& Novida Abbas, 1997. Pulau Bawean, titik persinggahan di periaran utara Jawa. Sebuah catatan tentang peninggalan kepurbakalaannya, dalam: Inajati Adrisijanti et al. (eds.) Cinandi. Yogyakarta: Panitia Lustrum VII Jurusan Arkeologi FS UGM, hal. 80--90

Lee, Everett S. 1995. Teori Migrasi (diterjemahkan oleh Hans Daeng). Yogyakarta: Pusat Penelitian Kependudukan UGM

Lekkerkerker, C. 1935. Sapoedi en Bawean, overbevolking en ontvolking, dalam KT 24, hal. 459--476

Mills, JV. 1979. Chinese Navigators in Indulinde about AD 1500, dalam Archipel 18, hal. 69--93

Sopher, David E. 1977. The Sea Nomads. Singapore: National Museum

Sulaiman. 1981/1982. Gerabah Madura. Jakarta: Depdikbud 1983/1984. Kerapan Sapi Di Madura. Jakarta: Depdikbud

Vasanty, Puspa. 1976. Kebudayaan Orang Tionghoa Di Indonesia, dalam: Koentjaraningrat (ed.), Manusia Dan Kebudayaan Di Indonesia. Jakarta: Djambatan, hal. 346--366 


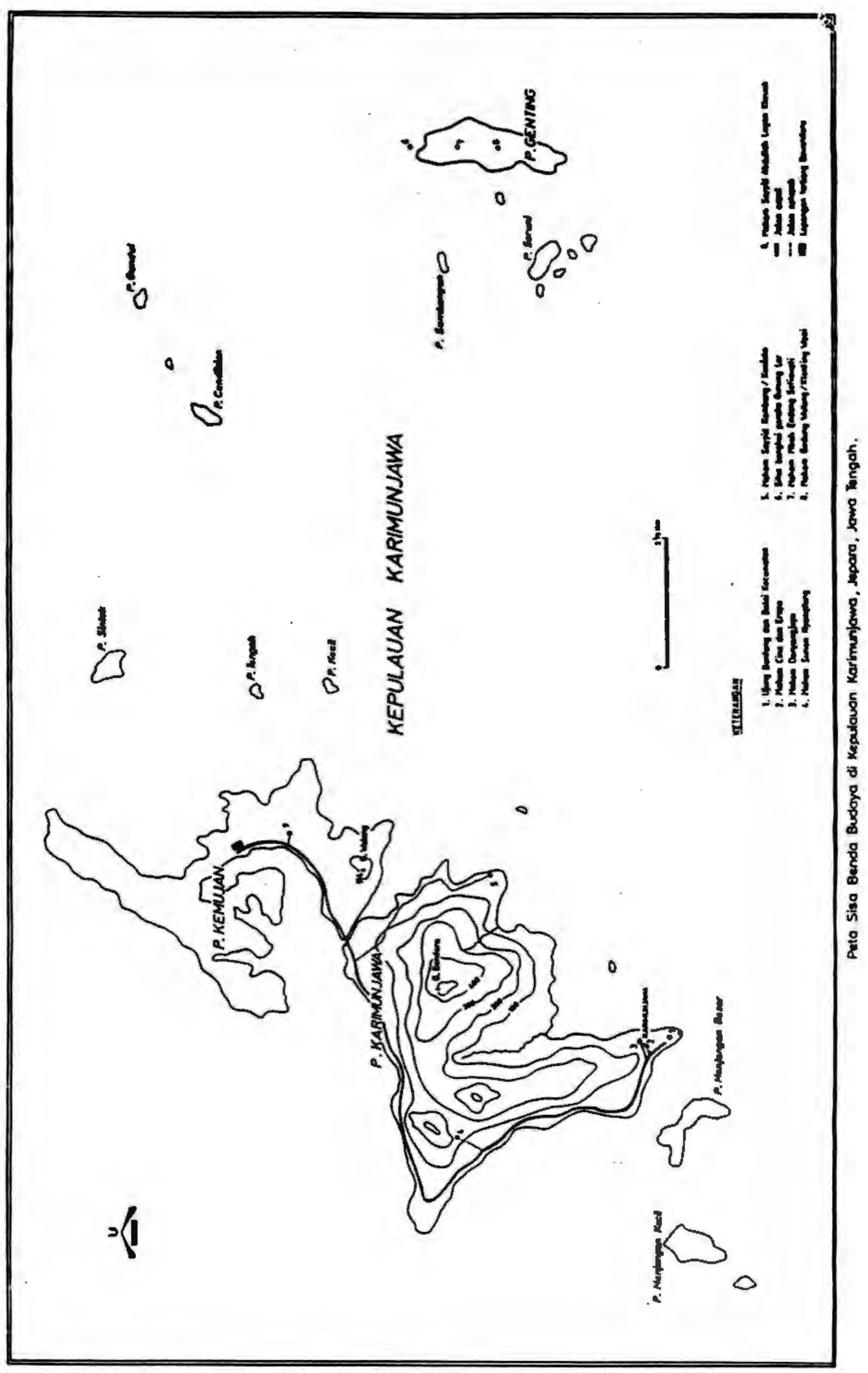

